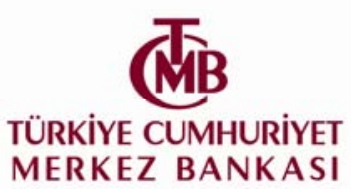

\title{
CBT RESEARCH NOTES IN ECONOMICS
}

\section{Inflation Dynamics in Turkey: In Pursuit of a Domestic Cost Measure ${ }^{1}$ \\ Selen Başer Hande Küçük Fethi Öğünç}

Abstract: We provide Bayesian estimates of the hybrid New Keynesian Phillips Curve
(NKPC) to explain the dynamics of the consumer price inflation in Turkey, focusing particularly on the domestic component of the real marginal cost. We find that the baseline model which uses current and lagged values of the output gap as a measure of the domestic real marginal cost does a better job at accounting for the consumer price inflation in Turkey compared to alternative models which incorporate the unit labor cost. On the other hand, estimations of the hybrid NKPC for the services inflation point to the importance of the unit labor cost for the inflation dynamics in this sector.

Özet: Bu çalışmada Bayesçi yöntemler kullanılarak Türkiye için Yeni Keynesçi Phillips Eğrisi (NKPC) tahminleri elde edilmekte; özellikle yurt içi kaynaklı maliyet baskılarının enflasyon üzerindeki etkileri üzerinde durulmaktadır. Yurt içi reel marjinal maliyet ölçütü olarak çıktı açığını kullanan baz modelin, reel birim ücret serilerini içeren alternatif modellere göre TÜFE enflasyonunu açıklamakta daha başarılı olduğu bulunmuştur. Diğer taraftan, hizmet enflasyonu için yapılan NKPC tahminleri, reel birim ücretlerin bu sektördeki enflasyon dinamikleri üzerinde önemli rol oynadığını göstermektedir.

\section{Introduction}

Understanding inflation dynamics is of utmost importance for an inflation-targeting central bank. In this study, we present estimations of the hybrid New Keynesian Phillips Curve

\footnotetext{
${ }^{1}$ We thank Burcu Gürcihan for providing us detailed information about the unit labor cost data. We also thank Hakan Kara and two anonymous referees for helpful comments and suggestions. The views expressed herein are solely of the authors and do not represent those of the Central Bank of the Republic of Turkey or its staff.
} 
(NKPC) to shed light on inflation dynamics in Turkey. The hybrid NKPC simply implies that inflation today is a function of lagged inflation, expected future inflation and real marginal cost. $^{2}$ While the impact of foreign cost measures on Turkish inflation is well-studied, there is little work done on the appropriate measures of domestic costs and their impact on inflation. ${ }^{3}$ We aim to fill this gap by focusing on the domestic component of the real marginal cost, analyzing possible proxies for domestic cost pressures in a NKPC setting. In addition, our methodology makes it possible to obtain estimates for the real marginal cost and its domestic and foreign components, which are not observed directly in the data.

We use quarterly data that starts from 2003 to account for the structural change experienced in the Turkish economy after the 2001 crisis. Given the size of our sample, we resort to Bayesian estimation, which is known to outperform GMM and maximum likelihood in small samples. ${ }^{4}$ The inflation measure used in the estimations is based on the CPI excluding unprocessed food, alcoholic beverages and tobacco, which are the CPI subcomponents with the highest unexpected volatility. ${ }^{5}$ We also report alternative estimations with services sector inflation. As a measure of cost-driven inflationary pressures, we construct a total cost measure and divide it into foreign and domestic components. The foreign cost measure is estimated as a function of import prices in domestic currency whereas the domestic cost measure is modeled with the output gap in the baseline case and with alternative variables in the competing cases. Specifically, we use a variety of real unit labor cost (ULC) indicators and a linear combination of output gap and ULC that can be considered as capturing nonlabor and labor costs.

Our results suggest that output gap is a better proxy to measure the domestic cost pressures on CPI based inflation compared to the unit labor cost. On the other hand, unit labor cost is found to be an important determinant of the services inflation.

\section{Labor Cost Indicators in Turkey}

Output gap is commonly used as a measure of the real marginal cost in estimations of the NKPC. ${ }^{6}$ However, as argued by Galí and Gertler (1999), there are certain drawbacks of using output gap in NKPC estimations. Firstly, marginal cost directly covers the impact of productivity gains on inflation which is a point that traditional output gap measures often

\footnotetext{
${ }^{2}$ It is called "hybrid" because it depends on both expected inflation as the NKPC theory originally implies, and on past inflation as in an adaptive expectations framework. We refrained from resorting to the pure forward-looking NKPC in the estimations given the apparent persistence in inflation for Turkey in the period under consideration.

${ }^{3}$ See Kara and Öğünç (2012) for a recent analysis of exchange rate and import price pass-through in Turkey. Existing studies like Yazgan and Yılmazkuday (2005), Agénor and Bayraktar (2010) and Saz (2011) who estimate NKPC for Turkey using different specifications in different samples find mixed results on the relevance of domestic cost measures on inflation.

${ }^{4}$ See Rabanal and Rubio-Ramirez (2005) for other advantages of the Bayesian estimation.

${ }^{5}$ Hereafter we use the term CPI for the CPI excluding unprocessed food, alcoholic beverages and tobacco.

${ }^{6}$ Theoretically, it is possible to show that real marginal cost is proportionate to output gap under certain assumptions. See Rotemberg and Woodford (1999).
} 
miss. Secondly, theoretical conditions under which output gap is proportionate to real marginal cost might not be satisfied. Finally, there might be a discrepancy between the two measures in the data especially in terms of their lead-lag relationship. In this respect, it is important to investigate if using other measures of domestic real marginal costs improves the fit of the NKPC for Turkey.

One measure of domestic real marginal cost is the real unit labor cost, which in turn is equivalent to labor income share, and is given by:

$$
\mathrm{ULC}=\frac{W / P}{Y / L}
$$

where $W$ denotes the wage rate, $P$ is the $C P I, Y$ is real output and $L$ is employment. Following the literature, we start by using the traditional output gap as a domestic cost measure and take this model as the baseline. Then, we employ ULC as an alternative domestic cost measure. This is based on the fact that labor costs make up a non-negligible part of total operating costs of firms across the whole economy in Turkey (Karadaş et al., 2006). The share of labor costs in total costs seems to be around 12 percent on average in manufacturing sector and even more in labor intensive services sector. ${ }^{7}$

To construct ULC series we need data for the wage rate, $W$. We consider mainly two different series for $W$; minimum wage rate and total nonfarm gross wage payments divided by total employment. Hence, we have two different ULC series, namely ULC ${ }^{\text {MIN }}$ and ULC'. $U_{L C}{ }^{\text {MIN }}$ stands for the real unit labor cost computed with minimum wage rate while ULC ${ }^{\top}$ represents the real unit labor cost calculated using total nonfarm gross wage payments over total employment. ${ }^{8}$

Figure 1 plots the ULC ${ }^{\mathrm{MIN}}$ and ULC ${ }^{\top}$ series alongside the output gap measure. ${ }^{9}$ Firstly, both ULC measures move closely together. In particular, the contemporaneous correlation between ULC ${ }^{\text {MIN }}$ and ULC ${ }^{\top}$ is $0.92 .^{10}$ Secondly, output gap is more persistent than the ULC measures. Thirdly, the ULC measures tend to lag the output gap, which is also the case for the US as documented by Galí and Gertler (1999). Due to the sluggish response of labor income share to output gap, the contemporaneous relation between the two measures is

\footnotetext{
${ }^{7}$ The share of services in GDP at current prices is about 55 percent, while that of manufacturing (industry) is around 16 (20) percent for recent years. If the construction sector is included, the figure for services rises to 60 percent.

${ }^{8}$ Alternative to the minimum wage rate and total wage payments over total employment series, we also considered the wage rate in manufacturing sector and employed a ULC measure, ULC ${ }^{\text {MAN }}$, accordingly. Table 1 shows that sum of squared errors of the NKPC estimation with ULC ${ }^{\text {MAN }}$ is considerably close to that of the one with ULC ${ }^{\text {MIN }}$ or ULC ${ }^{\top}$. However, manufacturing industry represents a limited part of the whole economy. Therefore, we choose to discuss the results of NKPC estimations with ULC ${ }^{\text {MIN }}$ and ULC ${ }^{\top}$ in Section 4.

${ }_{9}^{9}$ Output gap is defined as the logarithmic difference between GDP and potential output and is a revised estimate of Alp, Öğünç and Sarıkaya (2012) who treat output gap as a latent variable in a small open economy New Keynesian model which is estimated using Bayesian methods.

This is consistent with the fact that minimum wage earners (unskilled labor) have a considerable share in total wage payments as shown in Başkaya and Özmen (2013).
} 
negative $^{11}$ (Figure 2). These observations suggest that output gap and ULC might have different information content for short-term inflation dynamics.

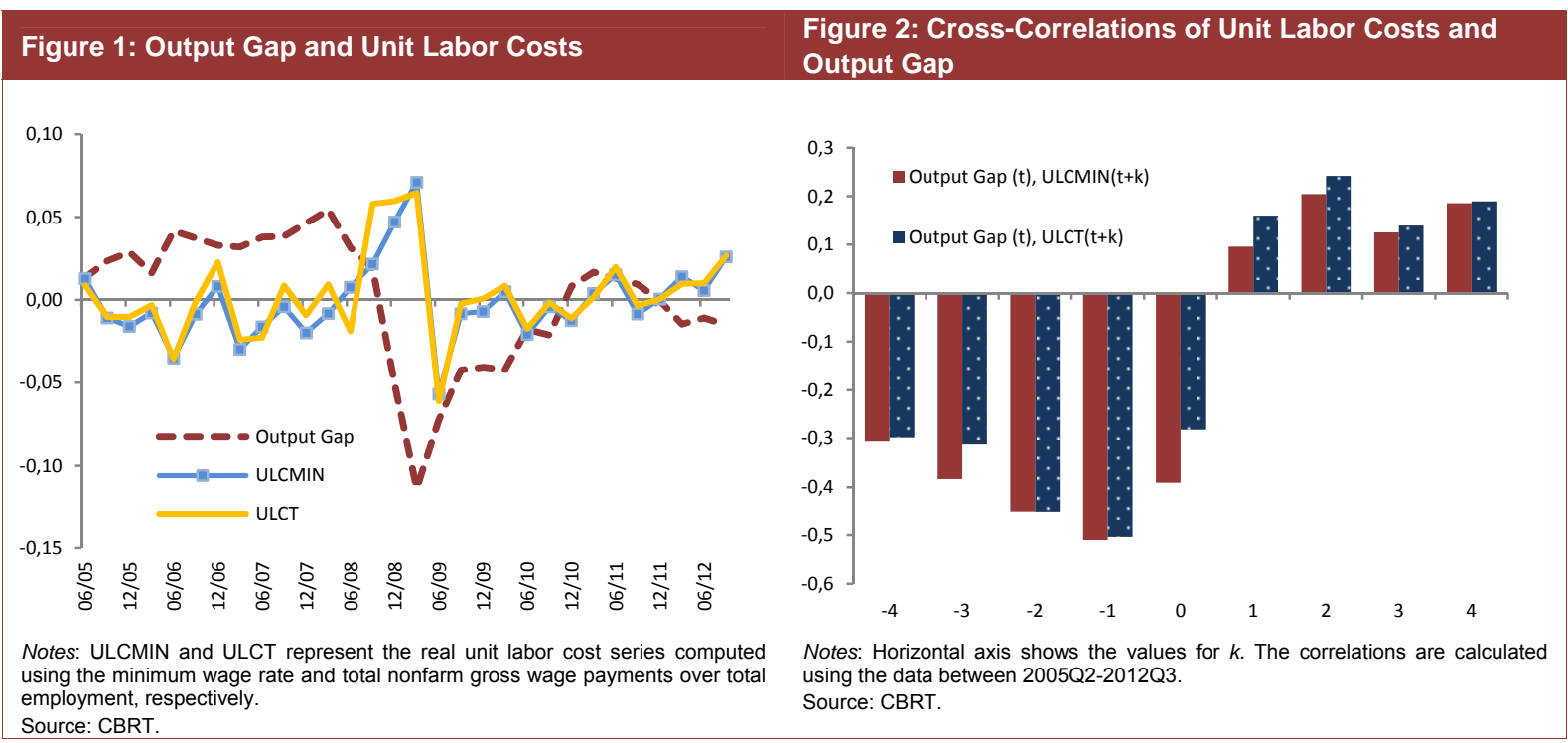

\section{Modeling and Estimation}

\subsection{Baseline Model}

We consider a hybrid New Keynesian Phillips curve specification that is widely used in the literature: ${ }^{12}$

$$
\pi_{t}=\gamma_{b} \pi_{t-1}+\gamma_{f} E_{t} \pi_{t+1}+\lambda r m c_{t}+\varepsilon_{t}^{\pi}
$$

where $\gamma_{b}+\gamma_{f}=1, \pi_{t}$ is the annualized quarter-on-quarter change in the seasonally adjusted $C P I, E_{t} \pi_{t+1}$ is the expected future inflation, and $r m c_{t}$ denotes total real marginal cost defined as a weighted sum of domestic $\left(r m c_{t}^{d}\right)$ and foreign $\left(r m c_{t}^{f}\right)$ components:

$$
r m c_{t} \equiv \zeta r m c_{t}^{d}+(1-\zeta) r m c_{t}^{f} \text {. }
$$

In equation (2), $\gamma_{b}$ and $\gamma_{f}$ give the importance of backward and forward-looking behavior in price-setting, respectively. $\lambda$ denotes the sensitivity of inflation to $r m c_{t}$ and $\varepsilon_{t}^{\pi}$ is a costpush shock. $\zeta$ in (3) denotes the weight of the domestic component in total $r m c_{t}$. There is a high import content in domestic production in Turkey. According to Karadaş et al. (2006), costs associated with imported raw materials and equipments constituted of about 36 percent of total operating costs of manufacturing firms in 2004. The weight of the foreign cost component is even higher when we take into account the import content of energy and

\footnotetext{
${ }^{11}$ This negative relationship is the most apparent in the financial crisis episode and towards the end of sample period

${ }^{12}$ See Galí and Gertler (1999) for the details of NKPC theory including the derivation.
} 
domestic intermediate and capital goods. Specifying a foreign component to the total real marginal cost is also in line with previous papers that derive the NKPC for an open economy that uses intermediate imported inputs in production such as Svensson (2000). The foreign component of the real marginal cost reflects the costs related to imported inputs as well as the exchange rate, and is specified as:

$$
r m c_{t}^{f}=\mu_{1} \pi_{t}^{M, d}+\mu_{2} \pi_{t-1}^{M, d}+\left(1-\mu_{1}-\mu_{2}\right) \pi_{t-2}^{M, d} .
$$

where $\pi_{t}^{M, d}$ denotes the quarterly change in import prices in domestic currency and is exogenous to the model. ${ }^{13}$

We consider alternative specifications for the domestic component of real marginal cost, $r m c_{t}^{d}$, which involve output gap or ULC, or both. In the baseline model, domestic real marginal costs only depend on the current and lagged values of output gap, $\tilde{y}_{t}$ :

$$
r m c_{t}^{d}=\omega_{1} \tilde{y}_{t}+\omega_{2} \tilde{y}_{t-1}+\left(1-\omega_{1}-\omega_{2}\right) \tilde{y}_{t-2}
$$

Output gap denotes the difference between actual and potential output and is determined outside the model. The lag structure in equation (5) reflects our prior that inflation is sluggish to adjust to indicators related to real economic activity. In the first alternative specification to equation (5), we utilize ULC instead of the output gap. Therefore, $r m c_{t}^{d}$ is written as equation $\left(5^{\prime}\right)$.

$$
r m c_{t}^{d}=\tau_{1} \mathrm{ULC}_{t-1}+\tau_{2} \mathrm{ULC}_{t-2}+\tau_{3} \mathrm{ULC}_{t-3}+\tau_{4} \mathrm{ULC}_{t-4}+\varepsilon_{t}^{c d}
$$

The contemporaneous negative correlation between the labor income share and the output gap documented in the previous section may imply that these two variables are capturing different aspects of domestic real marginal costs such as labor and non-labor; hence both may be relevant for explaining inflation dynamics at least in the short run. Accordingly, in another alternative specification, we let $r m c_{t}^{d}$ be a function of both the output gap and ULC and specify $r m c_{t}^{d}$ as in Equation (5"):

$$
r m c_{t}^{d}=\Omega_{1} \tilde{y}_{t}+\Omega_{2} \mathrm{ULC}_{t-1}+\Omega_{3} \mathrm{ULC}_{t-2}+\Omega_{4} \mathrm{ULC}_{t-3}+\Omega_{5} \mathrm{ULC}_{t-4}+\varepsilon_{t}^{c d u}
$$

\section{Results}

The models specified above are estimated with Bayesian methods using quarterly data starting from 2003. Details of the estimation methodology, the data and the choice of priors for the lag structure and model parameters are given in the Appendix. ${ }^{14}$

\footnotetext{
${ }^{13}$ See the Appendix for a description of how priors about the lag structure are formed
} 


\subsection{Baseline Model}

Table 1 reports the baseline model estimates for two different sample periods. We start the first sample with 2003 to exclude the effects of the 2001 economic crisis and to go with the same CPI $(2003=100)$ throughout the analysis. Our choice of the second sample is determined by the fact that the ULC measures we construct are only available after 2005.

\begin{tabular}{|c|c|c|c|c|c|c|c|}
\hline \multirow[b]{3}{*}{ Parameter } & \multirow{2}{*}{\multicolumn{3}{|c|}{ Prior }} & \multicolumn{2}{|c|}{ 2003Q2-2012Q3 } & \multicolumn{2}{|c|}{ 2005Q2-2012Q3 } \\
\hline & & & & & osterior & \multicolumn{2}{|c|}{ Posterior } \\
\hline & Dist. & Mean & Std. & Mean & $95 \% \mathrm{Cl}$ & Mean & $95 \% \mathrm{Cl}$ \\
\hline$\gamma_{b}$ & Beta & 0.60 & 0.10 & 0.56 & $(0.44,0.70)$ & 0.49 & $(0.40,0.60)$ \\
\hline$\gamma_{f}$ & & 0.40 & & 0.44 & & 0.51 & \\
\hline$\lambda$ & Beta & 0.25 & 0.10 & 0.16 & $(0.07,0.23)$ & 0.17 & $(0.10,0.24)$ \\
\hline & \multicolumn{6}{|c|}{ Cost Shares } & $(0.014,0.024)$ \\
\hline$\zeta$ & Beta & 0.50 & 0.15 & 0.42 & $(0.20,0.64)$ & 0.36 & $(0.14,0.55)$ \\
\hline$(1-\zeta)$ & & 0.50 & & 0.58 & & 0.64 & \\
\hline \multicolumn{8}{|c|}{ Foreign Cost Measure } \\
\hline$\mu_{1}$ & Beta & 0.50 & 0.20 & 0.68 & $(0.43,0.95)$ & 0.72 & $(0.48,0.96)$ \\
\hline$\mu_{2}$ & Beta & 0.30 & 0.10 & 0.34 & $(0.16,0.50)$ & 0.33 & $(0.17,0.50)$ \\
\hline$\left(1-\mu_{1}-\mu_{2}\right)$ & & 0.20 & & -0.02 & & -0.05 & \\
\hline \multicolumn{8}{|c|}{ Domestic Cost Measure } \\
\hline$\omega_{1}$ & Beta & 0.40 & 0.20 & 0.48 & $(0.14,0.82)$ & 0.51 & $(0.17,0.84)$ \\
\hline$\omega_{2}$ & Beta & 0.40 & 0.20 & 0.44 & $(0.11,0.77)$ & 0.46 & $(0.10,0.78)$ \\
\hline$\left(1-\omega_{1}-\omega_{2}\right)$ & & 0.20 & & 0.08 & & 0.03 & \\
\hline SSE of NKPC & & & & 0.0162 & & 0.0088 & \\
\hline Average Acceptanc & per Chain & & & $25 \%$ an & $26 \%$ & $27 \%$ & \\
\hline
\end{tabular}

The findings based on the period over 2003Q2-2012Q3 suggest that the estimate of $\gamma_{b}$ is 0.56 while that of $\gamma_{f}$ is 0.44 . Hence, the backward-looking behavior is slightly dominant in shaping the inflation dynamics. However, the estimate of the degree of backwardness drops once we focus on more recent dynamics, i.e. considering the period starting from 2005Q2. ${ }^{15}$ In particular, the estimate of $\gamma_{b}$ is 0.49 versus 0.51 for $\gamma_{f}$. This finding can be reconciled with the fact the more recent sample gives more weight to the period of explicit inflation-targeting regime which was adopted in 2006. Again in this latter period, the sum of squared errors (SSE) of the NKPC is 0.0088 , half of the one obtained using the first sample. This is in line with the fact that the more recent sample characterizes a more stable period in the Turkish economy in terms of domestic fundamentals including the apparent improvement in the fiscal

\footnotetext{
${ }^{14}$ The working paper version of this document includes the technical details about the estimation methodology and the choice of priors and is available from authors upon request.

${ }^{15}$ Using a different context, Başkaya, Gülşen and Kara (2012) show that inflation expectations are less sensitive to the lagged inflation compared to the inflation target and forecasts. They also report that the impact of lagged inflation on inflation expectations has decreased over time.
} 
situation. To the extent that these provide a ground for giving more weight to the results of the period over 2005Q2-2012Q3, we can conclude that forward-looking behavior is at least as important as the backward looking behavior for the CPI inflation dynamics in Turkey.

The coefficient on the total real marginal cost $\lambda$ is around 0.17 in both sample periods. The share of foreign real marginal cost, $1-\zeta$, is found to outweigh that of domestic real marginal cost. Besides, $1-\zeta$ gets quantitatively larger in recent period. An estimate of 0.64 for $1-\zeta$ is reasonably consistent with the high sensitivity of energy and core goods prices to external price pressures in Turkey. ${ }^{16}$ For instance, while the year-end inflation in 2011 was 10.45 percent, almost 5 percentage points of it was due to the rise in import prices and marked depreciation of the Turkish Lira (CBRT, 2012). The estimates of $\mu_{1}$ and $\mu_{2}$ are statistically significant, suggesting that current and lagged values of domestic currency denominated import prices are relevant for explaining foreign real marginal costs. ${ }^{17}$ In particular, the contemporaneous effect, $\mu_{1}$, is estimated to be more pronounced. Output gap shows a similar lag structure. However, the estimates of $\omega_{1}$ and $\omega_{2}$ are close to each other, indicating that current output gap and its first lag are almost equally important.

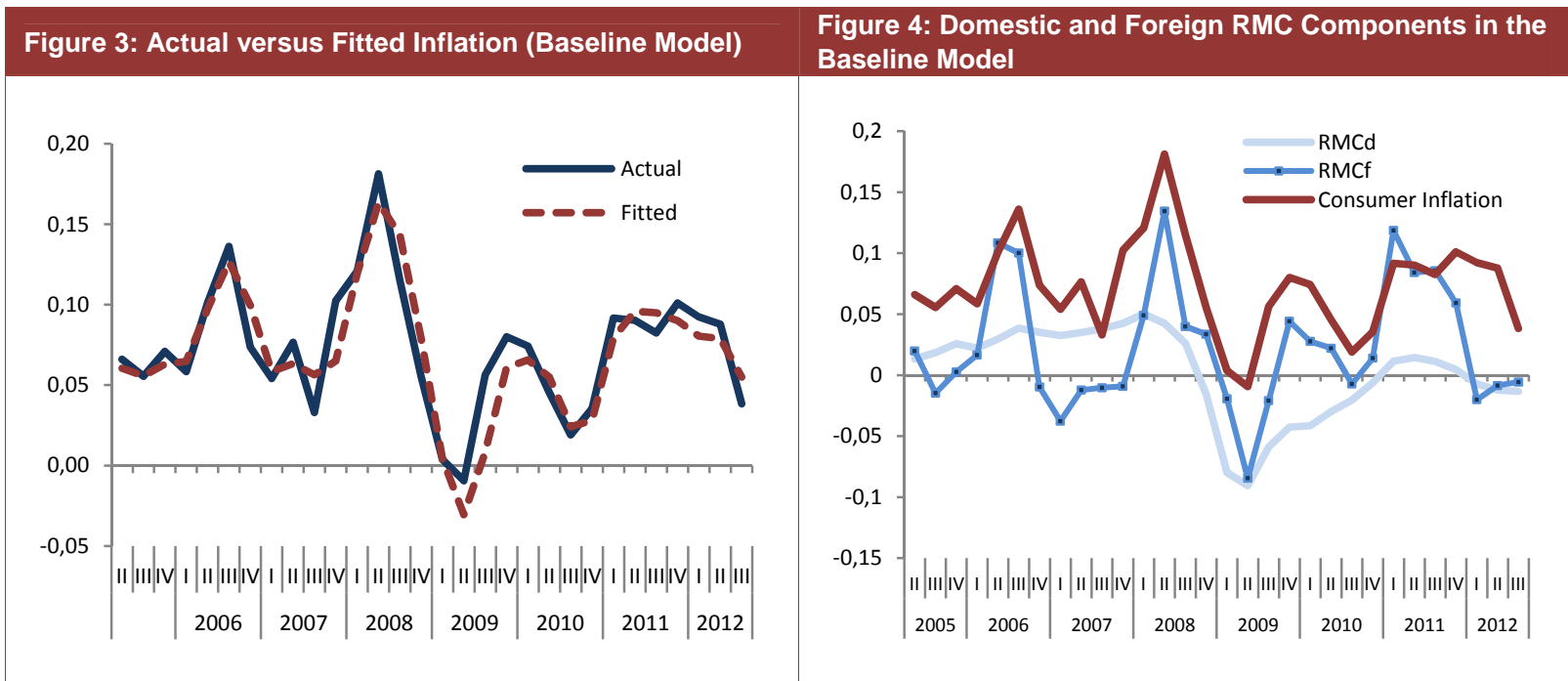

Overall, the baseline model, which uses output gap as a proxy for domestic real marginal costs, does a good job in capturing consumer inflation dynamics in Turkey (Figure 3). The turning points of inflation are largely determined by the foreign component of the real

\footnotetext{
${ }^{16}$ Core goods are goods excluding food, energy, alcoholic beverages, tobacco and gold.

17 Throughout the analysis, we use domestic currency denominated import prices in the estimations of the NKPC. An alternative approach would be to include dollar denominated import prices and exchange rate as separate variables, which might have different effects on inflation as shown by Yüncüler (2011). Given that the main focus of our analysis is on domestic cost measures, we do not go into detailed estimations of exchange rate and import price pass-through.
} 
marginal cost even though both components contribute to inflation dynamics (Figure 4). Looking at the recent period, both foreign and domestic marginal cost pressures appear to be benign, driving the consumer inflation down.

\subsection{Incorporating Labor Costs}

We now turn to the estimation results of the NKPC incorporating ULC in the domestic cost measure.

\begin{tabular}{|c|c|c|c|c|c|c|c|}
\hline \multicolumn{4}{|c|}{ Sample Period: 2005Q2-2012Q3 } & \multicolumn{2}{|c|}{$\begin{array}{c}\text { ULC }^{\top} \text { Based Model } \\
\text { Posterior }\end{array}$} & \multicolumn{2}{|c|}{$\begin{array}{c}\text { Output Gap and ULC } \\
\text { Based Model } \\
\text { Posterior }\end{array}$} \\
\hline Parameter & Dist. & Mean & Std. & Mean & $95 \% \mathrm{Cl}$ & Mean & $95 \% \mathrm{Cl}$ \\
\hline$\gamma_{b}$ & Beta & 0.60 & 0.10 & 0.59 & $(0.43,0.72)$ & 0.54 & $(0.41,0.68)$ \\
\hline$\gamma_{f}$ & & 0.40 & & 0.41 & & 0.46 & \\
\hline$\lambda$ & Beta & 0.25 & 0.10 & 0.22 & $(0.10,0.34)$ & 0.23 & $(0.11,0.33)$ \\
\hline $\begin{array}{l}\sigma_{\varepsilon} \pi \\
\text { Cost Shares }\end{array}$ & Inv.Gam & 0.025 & $\infty$ & 0.021 & $(0.016,0.028)$ & 0.019 & $(0.014,0.025)$ \\
\hline$\zeta$ & Beta & 0.50 & 0.15 & 0.36 & $(0.13,0.58)$ & 0.41 & $(0.17,0.64)$ \\
\hline \multicolumn{7}{|c|}{ Foreign Cost Measure } & \\
\hline$\mu_{1}$ & Beta & 0.50 & 0.20 & 0.76 & $(0.55,0.97)$ & 0.77 & $(0.57,0.97)$ \\
\hline$\mu_{2}$ & Beta & 0.30 & 0.10 & 0.34 & $(0.17,0.51)$ & 0.35 & $(0.17,0.51)$ \\
\hline$\left(1-\mu_{1}-\mu_{2}\right)$ & & 0.20 & & -0.10 & & -0.12 & \\
\hline \multicolumn{8}{|c|}{ Domestic Cost Measure } \\
\hline$\tau_{2}$ & Beta & 0.50 & 0.15 & 0.46 & $(0.21,0.70)$ & & \\
\hline$\tau_{4}$ & & 0.50 & & 0.54 & & & \\
\hline$\sigma_{\varepsilon^{c d}}$ & Inv.Gam & 0.02 & $\infty$ & 0.017 & $(0.005,0.033)$ & & \\
\hline$\Omega_{1}$ & Beta & 0.50 & 0.15 & & & 0.52 & $(0.29,0.77)$ \\
\hline$\Omega_{3}$ & Beta & 0.30 & 0.15 & & & 0.24 & $(0.04,0.44)$ \\
\hline$\Omega_{4}$ & Beta & 0.25 & 0.10 & & & 0.23 & $(0.08,0.38)$ \\
\hline$\Omega_{5}$ & Beta & 0.30 & 0.15 & & & 0.27 & $(0.04,0.48)$ \\
\hline$\sigma_{\varepsilon} c d$ & Inv.Gam & 0.02 & $\infty$ & & & 0.019 & $(0.004,0.038)$ \\
\hline \multicolumn{4}{|c|}{ SSE of NKPC } & \multicolumn{2}{|l|}{0.0123} & \multicolumn{2}{|c|}{0.0098} \\
\hline \multicolumn{4}{|c|}{ Average Acceptance Rate per Chain } & \multicolumn{2}{|l|}{$27 \%$} & \multicolumn{2}{|c|}{$25 \%$ and $26 \%$} \\
\hline \multicolumn{4}{|c|}{ SSE of NKPC with ULC ${ }^{\text {MIN* }^{*}}$} & \multicolumn{4}{|l|}{0.0118} \\
\hline \multicolumn{4}{|c|}{ SSE of NKPC with ULC ${ }^{\text {MAN }}$} & \multicolumn{4}{|l|}{0.0122} \\
\hline
\end{tabular}

Table 2 shows that employing ULC ${ }^{\top}$ instead of the output gap when modeling $r m c_{t}^{d}$ leads to a fall in the fit of the NKPC. The SSE increases by 40 percent to 0.0123 . Using ULC ${ }^{\text {MIN }}$ slightly improves the estimation compared to using ULC ${ }^{\top}$ but the model still underperforms 
compared to the baseline case. ${ }^{18}$ This does not mean that ULC measures are not important for consumer price inflation dynamics. What we emphasize is that output gap seems to be a better proxy for domestic real marginal cost in Turkey. In fact, in recent work, Başkaya and Özmen (2013) set out the importance of minimum wages for producer price inflation using panel data regressions.

When we use output gap and ULC together to model $r m c_{t}^{d}$, the fit gets better. However, as Table 2 presents, the SSE of the model, 0.0098, is still above the SSE of baseline model. The estimate of $\gamma_{\mathrm{b}}$ is larger than $\gamma_{\mathrm{f}}$ in models incorporating labor costs, implying a somewhat higher backward-looking behavior in inflation. This difference might be due to the fact that ULC is a less persistent series than the output gap (Figure 1). The higher persistence in the output gap series might be capturing some of the persistence in inflation dynamics in the baseline specification. However, given that the baseline model performs better than the models that include ULC, we attach a higher weight to the former when interpreting the determinants of the consumer price inflation in Turkey.

\subsection{Modeling Services Inflation}

Reaching the conclusion that including labor costs in $r m c_{t}^{d}$ does not help much to explain the CPI dynamics better, we turn to estimating the NKPC for services inflation using the same setup. Baseline and alternative models are as described by equations (2) to (5") with the only differences being the definition of inflation, which is now services inflation instead of the consumer price inflation; and the definition of the ULC. We employ the ULC measures calculated using the minimum wage series and total wage payments, both adjusted by services sector productivity (see equation (1)). ${ }^{19}$ Since services sector is intrinsically laborintensive, one could expect an improvement in the fit of the NKPC once the relevant ULC measure is incorporated.

Table 3 presents the estimation results. When $r m c_{t}^{d}$ is modeled solely using the output gap measure, the SSE of the model is 0.0044 . However, adding ULC ${ }^{\mathrm{MIN}}$ lowers the SSE by 52 percent to $0.0021 .{ }^{20}$ If we were to use ULC ${ }^{\top}$ instead of ULC ${ }^{M I N}$, there would still be improvement though to a lesser extent. This draws attention to the impact of the minimum wage rate on the prices of services. ${ }^{21}$ When the output gap and ULC ${ }^{\text {MIN }}$ are both included,

\footnotetext{
${ }^{18}$ We choose to discuss the results of the models with ULC ${ }^{\top}$ although ULC ${ }^{\text {MIN }}$ produces slightly smaller sum of squared errors. This is due to the fact that total wage payments over total employment is considered to be a better representative of the wage rate in total economy compared to the minimum wage rate.

${ }_{19}$ The ULC calculated using services sector wages move quite close to the ULC calculated using total wages. Both measures yield similar results in the estimations of the NKPC for services inflation.

${ }^{20}$ We also estimated the NKPC for services inflation using ULC MIN as the only proxy for $r m c_{t}^{d}$. Similar to the results discussed in Section 4.2 output gap and ULC ${ }^{\text {MIN }}$ based model has a smaller sum of squared errors than ULC ${ }^{\text {MIN }}$ based model, which has an SSE of 0.0035 . Therefore, we only present the results of the former in Table 3.

1 Başer, Kösem and Öğünç (2012) point out that minimum wage rate might be particularly influential on the catering services among other services subgroups.
} 
estimates on lagged versus future services inflation are 0.71 and 0.29 , respectively. This suggests that the degree of backwardness is quantitatively larger in services compared to the broad inflation measure at hand.

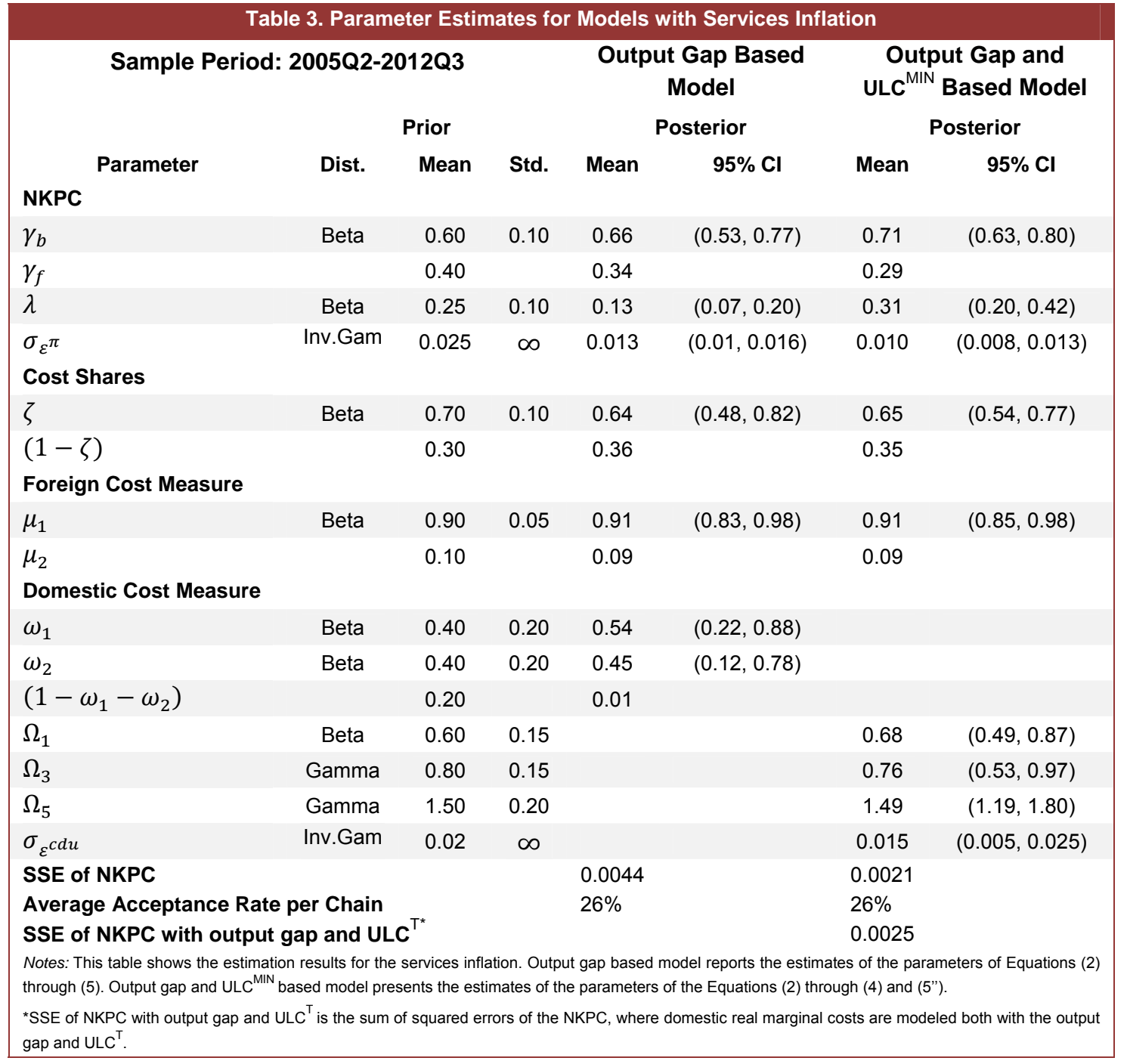

The share of domestic real marginal costs $\zeta$ is estimated to be 0.65 , implying that domestic costs have a larger impact on services inflation relative to foreign costs. This is just the opposite of what we find for the $\mathrm{CPI}$, for which foreign costs dominate the total cost structure of operating firms owing to the comparatively greater share of core goods which are vastly sensitive to external prices. A change in import prices is substantially and simultaneously reflected on foreign costs. The estimate on the lag of import prices, $1-\mu_{1}$, is only 0.09. Although the effect of foreign costs on services inflation is much lower than on $C P I$ inflation, it is still significant. This might be partly explained by the fact that services include items like transportation and catering, which also depend on external factors. Additionally, 
some of the services, such as package holidays, accommodation and those including maintenance and repair works appear to be influenced by the exchange rate developments.

To sum up, we can draw three main conclusions from these estimations: (i) backwardlooking behavior predominates the dynamics of services inflation, (ii) inflation in this sector is mostly driven by the domestic cost pressures as expected, and (iii) unit labor cost developments, in particular those that are based on minimum wages, seem to have a significant impact on prices of services.

Figures 5 and 6 illustrate how services inflation is related to the estimated total and domestic real marginal cost measures, respectively. Firstly, the total marginal cost estimate moves quite close to its domestic counterpart as can be seen by comparing the dashed blue lines in Figures 5 and 6 . Secondly, services inflation is quite closely related to the estimated real marginal cost measure. The turning points in services inflation seem to follow those in the real marginal cost measures.
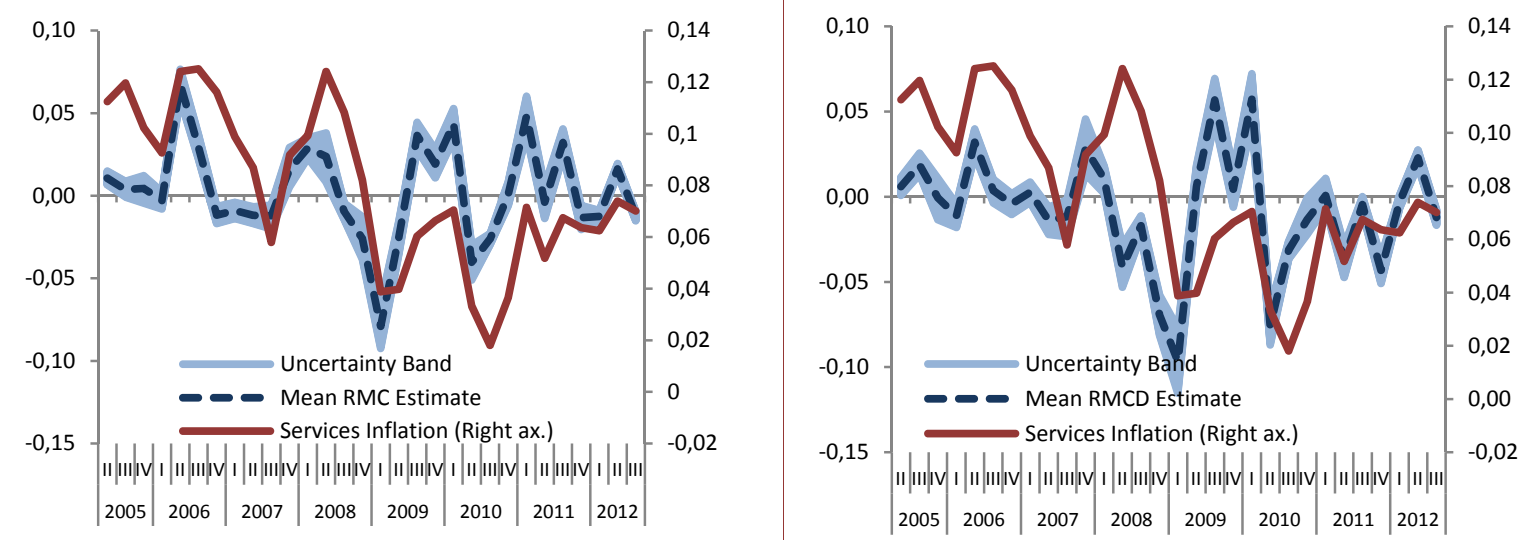

\section{Conclusion}

We present Bayesian estimates of the hybrid NKPC to explain the dynamics of the consumer price inflation in Turkey, focusing particularly on the domestic component of the real marginal cost. We find that the baseline model, which uses current and lagged values of the output gap as a measure of the domestic real marginal cost does a better job at accounting for the consumer price inflation compared to alternative models that incorporate unit labor costs. According to the baseline model estimated for the period between 2005Q2 and 2012Q3, backward and forward-looking inflation terms are found to be equally important for current inflation. This indicates a slight decline in the role of backward-looking behavior 
compared to the period that starts with 2003Q2. Besides, the share of the domestic component in total real marginal cost is estimated to be around 40 percent.

When we estimate the hybrid NKPC for services inflation, we find a more important role for the domestic component in total real marginal cost with a share of about 65 percent. In particular, the minimum wage based measure appears to be closely related to services inflation. This seems plausible in the sense that services sector utilizes a higher share of labor input and a lower share of imported inputs compared to non-service sectors. As a final point, the backward-looking pricing behavior is found to be predominant, with a coefficient of 0.7 on lagged inflation in the NKPC for services inflation. 


\section{References}

Alp, H., Öğünç, F., Sarıkaya Ç., 2012. Monetary Policy and Output gap: Mind the Composition. CBT Research Notes No:12/07.

Agénor, P.-R., Bayraktar, N., 2010. Contracting models of the Phillips Curve empirical estimates for middle income countries. Journal of Macroeconomics 32, 555-570.

Başer, S., Kösem, S., Öğünç, F., 2012. Türkiye'de Enflasyon: Sektörel ve Uluslararası Bazda Karşılaştırmalı Bir Analiz ve Öne Çıkan Noktalar. CBT Research Notes No:12/20.

Başkaya, Y. S., Gülşen, E., Kara, H., 2012. Inflation Expectations and Central Bank Communication in Turkey. Central Bank Review Vol.12/2, 1-10.

Başkaya, Y. S., Özmen, U., 2013. Türkiye'de Asgari Ücret-ÜFE Enflasyonu İlişkisi Üzerine Ampirik Bir Analiz. TCMB Ekonomi notu, yayımlanma aşamasında.

Central Bank of the Republic of Turkey, 2012. Open Letter Written to the Government Pursuant to Article 42 of the Central Bank Law, 31/01/2012.

Çebi, C., 2011. The Interaction between Monetary and Fiscal Policies in Turkey: An Estimated New Keynesian DSGE Model. CBT Working Paper No:11/04.

Galí, J., Gertler M., 1999. Inflation dynamics: A Structural Econometric Analysis. Journal of Monetary Economics 44, 195-222.

Kara, H., Öğünç F., 2012. Döviz kuru ve ithalat fiyatlarının enflasyona etkisi. İktisat İşletme ve Finans 27 (317), 9-28.

Karadaş, E., Mutluer, D.,Barlas-Özer, Y., Aysoy, C., 2006. Türkiye'de İmalat Sanayindeki Firmaların Fiyatlama Davranışı. CBT Working Paper No:06/02.

Rabanal, P., Rubio-Ramírez, J. F., 2005. Comparing New Keynesian models of the business bycle: A Bayesian approach. Journal of Monetary Economics 52, 1151-1166.

Rotemberg, J.J., Woodford, M., 1999. The cyclical behavior of prices and costs. In: Taylor, J.B., Woodford, M. (Eds.), Handbook of Macroeconomics, Vol. 1B. North-Holland, Amsterdam, pp.1051-1135.

Saz, G., 2011. The Turkish Phillips Curve Experience and the New Keynesian Phillips Curve: A Conceptualization and Application of a Novel Measure for Marginal Costs. International Research Journal of Finance and Economics 63, 8-45.

Svensson, L.E.O, 2000. Open-economy Inflation Targeting. Journal of International Economics 50(1), 155-183.

Yazgan, M. E., Yılmazkuday H., 2005. Inflation Dynamics of Turkey: A Structural Estimation. Studies in Nonlinear Dynamics \& Econometrics 9 (1), 1-13.

Yüncüler, Ç. 2011. "Pass-Through of External Factors into Price Indicators in Turkey," Central Bank Review, vol. 11(2), pp. 71-84. 


\section{Appendix: Estimation Methodology and Data}

Having a small sample, we use Bayesian approach to estimate model parameters. We quantify the prior means either based on the findings of some papers or by running a number of regressions. Specifically, for the lagged inflation coefficient $\left(\gamma_{b}\right)$, we set the mean of the prior distribution to 0.6 based on the findings of Çebi (2011). ${ }^{22}$ The coefficient $\lambda$ is set to 0.25 based on the authors' own GMM estimates. We stay agnostic for the share of domestic and foreign costs by setting the prior mean equal to 0.5 and adopt a higher standard deviation for this coefficient. The lag structure and coefficient values of the components of foreign costs are determined according to the findings of Kara and Öğünç (2012) on the pass-through from the Turkish lira denominated import prices to inflation in Turkey. The lag structure of the output gap measure originates from in-house studies of the CBT. We allow for substantial variation in these coefficients by setting a high standard deviation. For the models having unit labor cost as an element of the domestic cost measure, we set the prior means based on either using GMM estimation or running a number of regressions with a domestic cost measure proxy. ${ }^{23}$ Also note that we drop the insignificant lags of real unit labor costs. The models are estimated with Dynare. Results are obtained with 100000 draws of which the first half is discarded.

The data cover the period over 2003Q2-2012Q3. We measure inflation as the annualized quarterly change in the seasonally adjusted CPI excluding unprocessed food, alcoholic beverages and tobacco. ${ }^{24}$ We also estimate the hybrid NKPC with services inflation, which is computed as the annualized quarterly change in the seasonally adjusted services price index. To model the foreign component of the real marginal cost, we employ quarterly change in the import unit value index denominated in the Turkish lira. For the domestic component of the real marginal cost, we use the output gap, which is a revised estimate of Alp, Öğünç and Sarıkaya (2012), and real unit labor cost, which is measured with alternative wage rates; total non-farm gross wage payments over total employment and minimum wage rate. Since non-farm wage series are only available from 2005Q2, models incorporating labor costs cover the period 2005Q2-2012Q3.

\footnotetext{
The CBT Research Notes in Economics is a refereed publication prepared by Central Bank of Turkey with the purpose of disseminating results from research on the Turkish economy with a particular emphasis on macroeconomic developments and issues relevant for monetary policy, and thereby contributing to discussions on economic issues in a timely fashion. The views and opinions expressed in the CBT Research Notes in Economics do not necessarily represent the official views of the Central Bank of Turkey and its staff. This publication is edited by Yusuf Soner Baskaya. A written permission must be obtained to reprint the entire text of notes published in CBT Research Notes in Economics series. For questions and comments:

Editör, Ekonomi Notları, TCMB İdare Merkezi, İstiklal Cad, No: 10, Kat:15, 06100, Ulus/Ankara/Türkiye. E-mail:ekonomi.notlari@tcmb.gov.tr
}

\footnotetext{
${ }^{22}$ Çebi (2011) estimates the reduced form lagged inflation coefficient as 0.59 over the period 2002Q1-2009Q3 with Bayesian approach for GDP deflator and suggests that backward looking behavior remains predominant.

${ }^{23}$ To construct a domestic cost measure proxy, we simply estimate a CPI inflation equation with lagged inflation and three lags of TL denominated import price inflation then use the residuals of this equation as a proxy.

${ }^{24} \mathrm{CPI}$ excluding unprocessed food, alcoholic beverages and tobacco accounts for about 84.3 percent of the CPI.
} 